\title{
Smart-Technology Based Model of Managing the Development of the Regions: Smart Specialisation
}

\author{
Irina V. Filimonenko* and Zoya V. Vasilieva \\ Siberian Federal University \\ 79 Svobodny, Krasnoyarsk, 660041, Russia
}

Received 29.05.2017, received in revised form 08.12.2017, accepted 15.12.2017

\begin{abstract}
This research is focused on the justification of the necessity to change conceptual approaches to the management of the resource regions' economy development in the conditions of global challenges and changes in the models of spatial development. New world development trends decrease the efficiency of using traditional methods and mechanisms of the resource region's management, which are based on the preservation of the role of the leading raw resources sector; prevailing influence of large industrial and resource holdings; limited powers of regional authorities in managing the resource potential of the region.

Basing on the relation of technological and market parameters, the article studies the opportunities for applying models of multi-sectoral development to meet global challenges by forming a new rapidly developing sector in the economy of resource regions. Taking into account the peculiarities of the resource regions' development, the role of rapidly developing sectors in technological and innovative development of the region is revealed. To form new rapidly developing sectors in the economy of the regions, the authors justify application of the approach to region development management on the basis of "smart specialisation" concept through introduction of Smart technologies into the processes of production and administration both in traditional specialisation sectors and new spheres of activities. Using the "smart specialisation" concept for managing the resource region allowed to determine scenarios for the economy development differentiated by technological leadership scale - "niche leadership", "local technological competitiveness", "international technological competitiveness". Applying the strategic positioning method in the axis of the matrix space "economic sector-source of new knowledge and technologies/professional competences" allowed to form strategies and scenarios of technological development of the resource region. Parameters of strategic positioning included "technology (own, mother, borrowed)"; "professional competence (basic of the existing specialisation; innovative)"; "basic sectors of regional specialisation"; "new rapidly developing".

Assessment of the model of managing resource regions on the basis of "smart specialisation" concept on the example of the Krasnoyarsk Krai allowed to prove the hypothesis that there are "rapidly developing sectors" (high-tech, knowledge economy) in the economy structure and to determine necessary conditions for development and growth.
\end{abstract}

Keywords: region's development management, global challenges, multi-sectoral model, rapidly developing sector, "smart specialisation" concept, technological development scenarios.

DOI: 10.17516/1997-1370-0186.

Research area: economics.

(c) Siberian Federal University. All rights reserved

* Corresponding author E-mail address: IFilimonenko@sfu-kras.ru 
Relevance. The need to change conceptual approaches to managing the spatial development of territories is associated with key changes occurring in the world as a result of the impact of global challenges and the formation of new trends in territorial development. Key trends include global synchronisation in advanced industries, convergence and interpenetration of various fields of science and technology; change in the types of regional and urban development through the transition to "networked" development; active distribution of Smart Solution - smart and environmentally friendly technologies, the emergence of compact smart cities. As a consequence, the existing global value chains are being transformed, key players in global and national markets are changing, and the types of regional development are changing. At present, the cluster approach in regional policy is declared as an important tool for increasing the territories' competitiveness. The principal changes in the configuration of the world energy infrastructure, transport, information and communication systems are predicted.

Setting and description of the problem. In these conditions, one of the priority tasks of regional development is the search for new sources of economic growth (Innovatsionnyi Krai - 2020..., 2011). In the medium term, the solution of the problem is based on a largescale modernisation of traditional sectors of the economy based on modern technologies. In the long term, it is based on the creation of new industries that provide the formation of new markets or market niches, the creation of products with new properties, innovative services, and the achievement of significant multiplicative effects for the development of the region's economy due to their interdisciplinary and intersectoral nature.

However, when setting and finding solutions to the problems of regional development, it is necessary to take into account the specifics of the regions of the Russian Federation with the commodity-based economy, which manifests itself in the technological diversity and diversified specialisation of the economic sectors, the predominance of $3^{\text {rd }}$ and $4^{\text {th }}$ technological waves in the economy, in the dominance of large industrial holdings, in limited participation of regional authorities in management mechanisms development of resource and raw materials potential of the region. As a result, the transition to new technologies of the $5^{\text {th }}$ and $6^{\text {th }}$ technological waves slows down, it is difficult to implement new formats of interaction between regional authorities and economic agents of the system "science - education - production", it is more difficult to overcome the "fragmented" nature of the institutional environment and the infrastructural support for technological development. Therefore, new trends in world development reduce the effectiveness of using traditional methods and mechanisms for managing the region with the commodity-based economy, and there is a need to use new approaches to strategic planning for regional development based on the region's innovative technological potential and the model of multisectoral development. The catalyst for the development of the multisectoral model is the formation of the booming sector in the economy of the region, the growth of which is provided through the use of breakthrough technologies (cogno-, info-, nano-, bio-) and "knowledge economy" technologies by "constructing" production chains in the region (Corden, Neary, 1982; Corden, 1984; Ermakova; Mikheeva, 2009).

In this case, the priority task of searching for new sources of economic growth is transformed for the regions in the task of transition to a new multisectoral development model.

Despite the significant contribution of foreign (European Economic Commission, UN) and domestic scientists to the development of 
multisectoral models, the issues of formation of new sectors of the economy have not been previously considered, taking into account the peculiarities and limitations of the development of the commodity-based regions conditioned by the structure of the economy. This study, on the example of the Krasnoyarsk Krai, focuses on the possibilities of this model, allowing to reveal the mechanism of technological development of the region, to determine the necessary conditions and describe the effects that arise in a technologically multistructured economy due to the rapid development of one of the sectors.

Research methods. Let us consider the "economic sector" as a part of economic activity characterised by certain features that allow it to be distinguished from other parts of economic activity for analytical purposes (Sipols, 2010). When allocating sectors of the economy of the regions with the commodity-based economy, the criteria includes characteristics, combining which we can disclose the main purpose of the sector from the position of market parameters (aggregate supply and demand) used in the international economy, taking into account the possibilities of confronting the "global challenges" system. The characteristics of the sectors of the commoditybased economy is given in Table 1 .

The resources and raw materials sector produces products (raw materials, resources), mainly focused on meeting external demand (traded goods), prices are set by national or world markets. For the Krasnoyarsk Krai, this sector includes industries related to the third and fourth technological waves (Nazarova, 2007; Samusenko, Bukharova, 2015). The output of this sector is determined by the costs of specific factors (produced raw materials and natural resources) and labour resources.

The infrastructural sector produces nontradable goods (products, services), more focused on satisfying the domestic demand of the region, the consumption of which takes place at the place of production. Prices for goods are determined by local markets. The branches that make up this sector of the economy belong to the third and fourth technological waves. The output of the sector is determined by the costs of investment and highly professional labour resources, the size of domestic demand.

The high-tech sector is rapidly developing. The growth of the sector is due to the development of scientific and technical progress, the introduction and diffusion of innovations into the basic sectors of the economy, the formation of new technologies, industries and activities. The sector's products (new resources, materials, technologies, products, services) are able to claim global leadership in new sectors of the economy. Prices are determined in the external markets of the region. The types of activity that make up this sector of the economy are based on the technologies of the fifth and sixth technological waves. The output of this sector is determined by the costs of innovative and intellectual resources.

The "knowledge economy" sector has been developing as a result of achieving a synergistic effect from the integration activities of the regional production, consumption and R\&D centres. The products of the sector are the creation, dissemination and use of knowledge based on modern ICT for the development of smart technologies, industries, systems (ways to solve consumer problems, resource-efficient technologies for improving product quality, management methods for complex production and life support systems) technological competitiveness and world leadership of the region in new sectors of the economy. The formation of this sector is considered as a transition to the sixth technological wave of development (creation of artificial intelligence and global information networks). The intensity of the sector's development is determined by 
Table 1. Characteristics of the Sectors of the Region's Commodity-based Economy

\begin{tabular}{|c|c|c|c|}
\hline \multirow{2}{*}{$\begin{array}{l}\text { Parameters of the } \\
\text { sector's development }\end{array}$} & \multicolumn{3}{|c|}{ Sector of the region's economy } \\
\hline & $\begin{array}{l}\text { Resources and raw } \\
\text { materials }\end{array}$ & Infrastructural & High-tech \\
\hline Products & $\begin{array}{l}\text { Traded goods (raw } \\
\text { materials, resources), } \\
\text { mainly focused on meeting } \\
\text { external demand (traded } \\
\text { goods) }\end{array}$ & $\begin{array}{l}\text { Non-tradable goods } \\
\text { (products, services), more } \\
\text { focused on satisfying the } \\
\text { domestic demand of the } \\
\text { region }\end{array}$ & $\begin{array}{l}\text { Traded goods (new } \\
\text { resources, materials, } \\
\text { technologies, products, } \\
\text { services) focused on } \\
\text { satisfying both domestic } \\
\text { and external demand }\end{array}$ \\
\hline Prices & $\begin{array}{l}\text { Set by national or world } \\
\text { markets }\end{array}$ & Set by local markets & Set by world markets \\
\hline Technological wave & Third-forth & Third-forth & Fifth-sixth \\
\hline \multirow[t]{2}{*}{ Production factors } & $\begin{array}{l}\text { Produced raw materials, } \\
\text { natural resources, labour } \\
\text { resources }\end{array}$ & $\begin{array}{l}\text { Investment resources and } \\
\text { highly professional labour } \\
\text { resources }\end{array}$ & $\begin{array}{l}\text { Investment resources } \\
\text { Innovative and intellectual } \\
\text { resources }\end{array}$ \\
\hline & \multicolumn{3}{|c|}{ Knowledge economy } \\
\hline Products & \multicolumn{3}{|c|}{$\begin{array}{l}\text { Non-material products: knowledge, which is the basis for the development of ICT, } \\
\text { Smart technologies, production, systems }\end{array}$} \\
\hline Prices & \multicolumn{3}{|c|}{ Set by local or national intellectual property markets } \\
\hline Technological wave & \multicolumn{3}{|l|}{ Sixth } \\
\hline Production factors & \multicolumn{3}{|c|}{ Innovative, intellectual and information resources } \\
\hline
\end{tabular}

the structure of the innovation system, the costs of innovative and intellectual resources, and the development of the information infrastructure.

Sectoral composition of economic sectors of the Krasnoyarsk Krai and the change in their share in the gross regional product by 2020 are shown in Figure 1 (Innovatsionnyi Krai - 2020..., 2011; Strategies of innovative development...).

Effects from the development of the hightech sector and the "knowledge economy" sector are manifested in the resources and raw materials and infrastructural sectors of the economy, ensuring their transition to the fifth and sixth technological waves and output that can claim "local niche leadership" or "leadership in the local economy". Thus, rapidly developing sectors (high-tech, "knowledge economy") perform the role of an engine in the regional economy, ensuring the transition of basic, infrastructure industries and the economy as a whole to an innovative development model.
Taking into account the rapidly developing sectors in the model allows to achieve the following effects of regional development:

- to provide technological development of the resources and raw materials sector and infrastructural sector of the economy due to a wide range of multiplicative effects from the introduction of promising technologies. As a result, the technological multistructurality is reduced and the differentiation of innovative development in the economic sectors of the region is reduced;

- to protect the economy of the region from the risks of fluctuations of the external economic environment for raw materials and the negative impact of geopolitical factors;

- to increase budget receipts from all sectors of the economy, allowing to direct expenditures for the development of social infrastructure;

- to reduce the differentiation of the incomes of the regional population engaged in 


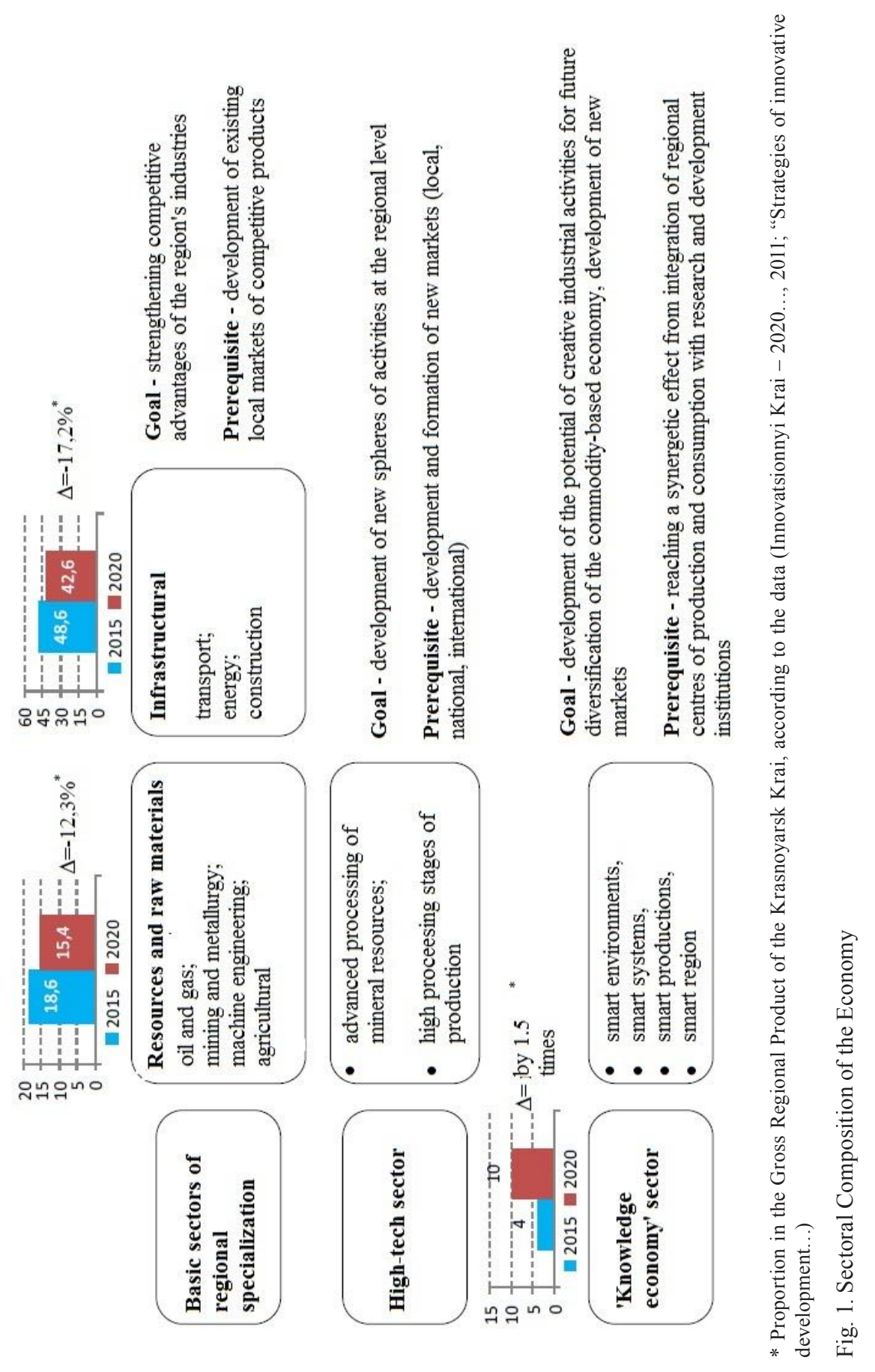


various sectors of the economy at the expense of the potential possibility to receive superprofits (profit growth) from the introduction and sale of innovative products (materials, technologies, goods, services);

- to limit intersectoral mobility of manpower by increasing the differentiation of requirements for the professional competences of workers in three sectors of the economy. As a result, the processes of training professional staff in the regional education system are becoming more understandable, and their forecasts are scientifically sound.

Effects from the development of the "knowledge economy" sector include the diversification of the economic structure of the region with the commodity-based economy, the provision of high added value in the manufacturing industries, the emergence of a fundamentally new level in the systems of governing the state and the society, the transition of the regional economy to the sixth technological wave, the output of products that can claim "world leadership in new sectors of the economy".

The prerequisite for the transition to a multisectoral model of the regional economy is the change in the principles of demand management for innovation based on network models and the concept of "smart specialisation". This concept is aimed at the formation of new rapidly developing sectors in the economy of the regions through the introduction of advanced, breakthrough and intelligent technologies in the production and management processes in the traditional specialisation areas of the region (resources and raw materials, infrastructure and processing) and the creation and development of new fields of activity. The sources of technologies and professional competences are not only the creation of their own mother technologies within the territory of the region, but their borrowing and adaptation.
Main results. For regions with a technologically multistructured economy, the concept of "smart specialisation" allows to design development scenarios differentiated in terms of technological leadership:

"niche leadership" is a scenario characterising, on the one hand, the processes of introducing regional production centers in the production and technological chains of the global economy and reproducing the products of the previous generation. On the other hand, the processes of transition to technologies and equipment of a new generation of high technology industries in the local sectors of the region's economy;

"local technological competitiveness" is a scenario based on the creation of mother technologies and innovative professional competences as the results of own research and development in the sectors of traditional specialisation of the region (resources and raw materials, infrastructure, processing);

"international technological competitiveness" is a scenario focused on applying the results of unique scientific research and technological developments (breakthrough technologies, integrator technologies, knowledge economy technologies) in new rapidly developing sectors of the economy.

The use of the method of strategic positioning in the coordinates of the matrix space "economic sector: the source of new knowledge and technologies/professional competences" allowed to design strategies for technological development of the region with the commoditybased economy (Regiony nuzhdautsia...; Smart specialization..., 2015) (Fig. 2). The following parameters of strategic positioning were used:

- technologies - "own mother" or "borrowed";

- professional competences _ "basic existing specialisation" or "innovative";

- sectors of the economy - "the basic sectors of regional specialisation (resource and 
raw materials, infrastructural)" or "new rapidly developing (high-tech, "knowledge economy")".

"Niche leadership" is a strategy based on the scenario of technology borrowing (technological imports). It is focused on the integration of the Russian economy into the most efficient and productive technological chains of the global economy. The parameters of the scientific and technological policy for the import of technologies practically do not depend on whether technological imports are concentrated in traditional or new sectors of the economy (Strategies of innovative...). It should be noted that the transition to a new generation of equipment in many high-tech industries in Russia, in particular in the telecommunications equipment industry, takes place in accordance with this strategy. Due to the lack of their own modern developments and developed production, the development of the industry is reduced to the reproduction of the previous generation products.

The strategy is aimed at maintaining macroeconomic stability in the region's economy characterised by relatively low parameters of budget expenditures on science, innovations and investments in the development of human capital.
The examples of this strategy in the Krasnoyarsk Krai can be the use of industrial biotechnology:

- in the mining industry: technologies using microorganisms in mining, coal, oil refining industry; technologies of bio-extraction of useful elements of non-traditional rocks;

- in the metallurgical industry: biohydrometallurgy is microbial leaching of metals from ores, production of corrosionresistant bimetals; biopreparations for oil production and transportation;

- in the energy sector: obtaining energy from renewable raw materials of biological origin on an industrial scale; biofuel: biogas, fuel pellets, briquettes.

"Local technological competitiveness" is provided through the creation of its own mother technologies and professional competences, which are necessary for use in the existing sectors of the economy of traditional specialisation (resource and raw materials, infrastructural). The strategy provides global leadership in the local market (domestic national or regional market) and the preservation of existing priorities in research and development.

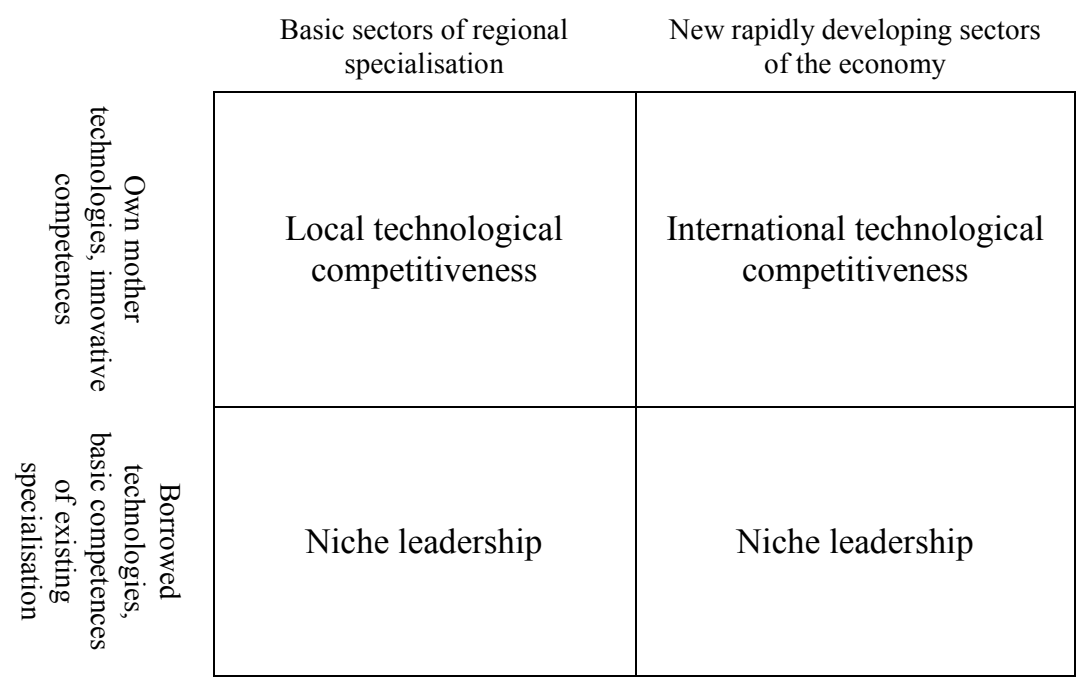

Fig. 2. Space of the strategical positioning of the region in accordance with the "smart specialisation" model 
A significant potential for the application of this strategy in the economy of the Krasnoyarsk Krai exists at the intersection of the following industry areas and technological innovations:

- in the machine building complex: utilization, processing of machine elements and light alloy structures at the end of the life cycle; utilization of dumps and waste from the mining industry;

- in the infrastructural sector: creation of a universal logistics and information operator on the basis of a postal operator for the service of cargo transportation between Europe and Asia; creation of spatial data infrastructure, distance education and media education.

"International technological competitiveness" is based on Russian scientific research and innovation and technological developments aimed at new branches of the economy, the development of a whole range of advanced production technologies, such as: agricultural biotechnology, genetic engineering, IT technology, urban engineering, engineering and industrial design, etc. This will require more significant investment in science, technology and innovation.

Potential of the strategy in the Krasnoyarsk Krai is concentrated in the following sectors:

- rocket and space: development of the GLONASS system: navigation spacecraft of the new generation, navigation equipment;

- radio electronics: creation of infrastructure in system-oriented design centres, design centres, silicon factories, scientific and technical centres for microsystems.

The strategy is capable of providing the world leading sectors of the economy with global leadership in the international market through unique scientific research and technological developments.

Required conditions for the implementation of technological development strategies are determined by the structure and potential of the region's innovation and technology system, which allows to assess either the possibility of creating their own mother technologies and the formation of innovative, professional competences in the region or the appropriateness of borrowing technologies and professional competences (Sergeev, Alekseenkova).

The implementation of technological development strategies depends on the possibility of forming the chain of a full innovative cycle, shifting the organizational and economic mechanisms and resources of the administrative management of the region from the production centres and consumption centres to $R \& D$ centres with a change in the conceptual management model: from the "production management" model to the model of "product's life-cycle management" (Fig. 3).

The production centres unite producers of intermediate and final products, including services, suppliers, intermediaries and other agents of the market, which provide the process of production of finished products (materials, technologies, goods, services). The objective in terms of development of the region is the formation of production and technology chains that include as many of the cycles of value creation as possible at all stages from mining to the provision of services.

Consumption centres (markets) are represented by sectoral complexes or geographical markets, where the main groups of industrial consumers are concentrated:

- resources and raw materials (oil and gas, mining-metallurgical, timber industry, machinebuilding, agro-industrial);

- infrastructural (construction, transport, energy);

$$
\text { - high-tech (biopharmaceutical, }
$$
processing of mineral resources, high production redistribution, high-tech production of innovative products);

- sector of the knowledge economy. 


\begin{tabular}{|c|c|c|}
\hline $\begin{array}{l}\text { 1. Production } \\
\text { centres }\end{array}$ & $\begin{array}{l}\text { 3. Consumption } \\
\text { centres/markets }\end{array}$ & \\
\hline Raw materials & \multicolumn{2}{|l|}{ Consumers } \\
\hline $\begin{array}{l}\text { Materials } \\
\text { Resources } \\
\end{array}$ & \multirow{2}{*}{$\begin{array}{l}\text { Resources and raw } \\
\text { materials sector: } \\
\text { Oil\&gas } \\
\text { Mining and metallurgy } \\
\text { Wood and paper } \\
\text { Machine building } \\
\text { Agricultural }\end{array}$} & \multirow{4}{*}{ 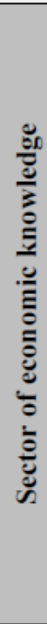 } \\
\hline $\begin{array}{l}\text { Technologies: } \\
\text { Design } \\
\text { Production } \\
\text { Management }\end{array}$ & & \\
\hline $\begin{array}{l}\downarrow \\
\text { Products } \\
\text { Services }\end{array}$ & $\begin{array}{l}\text { Infrastructural sector: } \\
\text { Construction } \\
\text { Transport } \\
\text { energy }\end{array}$ & \\
\hline & $\begin{array}{l}\text { High-tech sector: } \\
\text { Advanced processing of } \\
\text { mineral resources and raw } \\
\text { materials; high processing } \\
\text { stages of production }\end{array}$ & \\
\hline
\end{tabular}

The objective is to form the demand for innovative products and the formation of new markets.

$R \& D$ centres (product lifecycle management) combine the potential of research and innovation technological structures focused on the creation, examination, implementation and scaling of technology, as well as the formation of professional competencies. The objective is to use the opportunities provided by the national technological system to form the potential of the innovation and technological system of the region on the basis of cooperation between the subjects of the science-education-production system in order to achieve world technological competitiveness, transition to the $4^{\text {th }}$ technological wave and the development of the creative economy.

The structure of the potential of the region's innovative technological system for implementing scenarios and strategies for technological development is presented in Table 2. Fragments of the organizational and structural models of the technological development of the Krasnoyarsk Krai for the fuel and energy complex (the resource and raw materials sector of the economy) are shown in Fig. 4.

Conclusions. As the strategy of technological development is based on the choice of technologies capable of providing the region with different levels of technological leadership (niche, local, international), organizational and structural models are developed for each type of the strategy in each sector of the economy. As a result, the information field of technological development is formed reflecting the existing Centers of production of goods (services) in the region, the potential markets for them and the R\&D centres for technology development, implementation and scaling.

Thus, the assessment of the management model for the development of the regions with the commodity-based economy involving smart specialisation concept on the example of the Krasnoyarsk Krai made it possible to confirm the hypothesis of the presence of "rapidly developing sectors" (high-tech, knowledge economy) in the structure of the economy, to determine the necessary development 


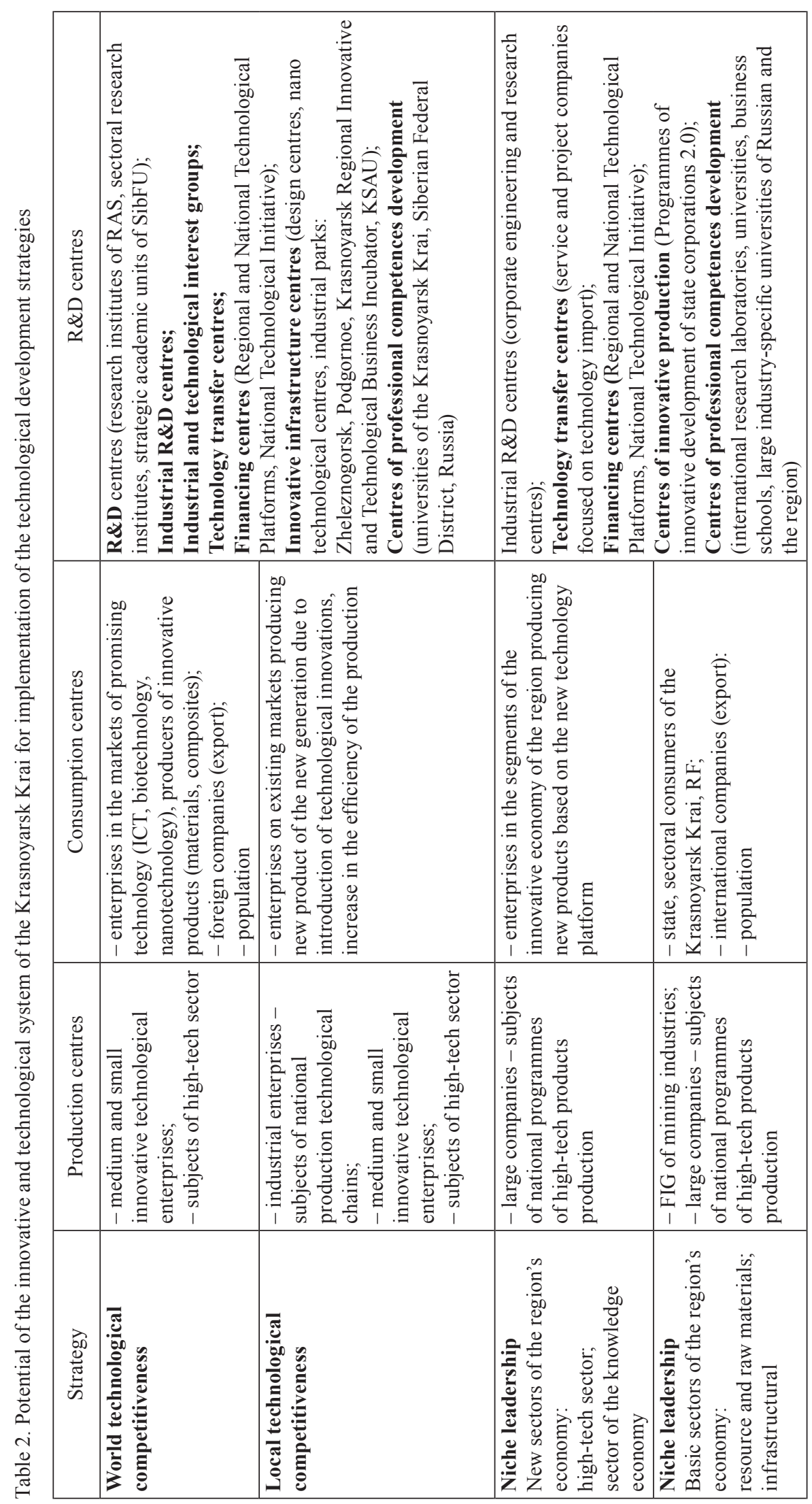




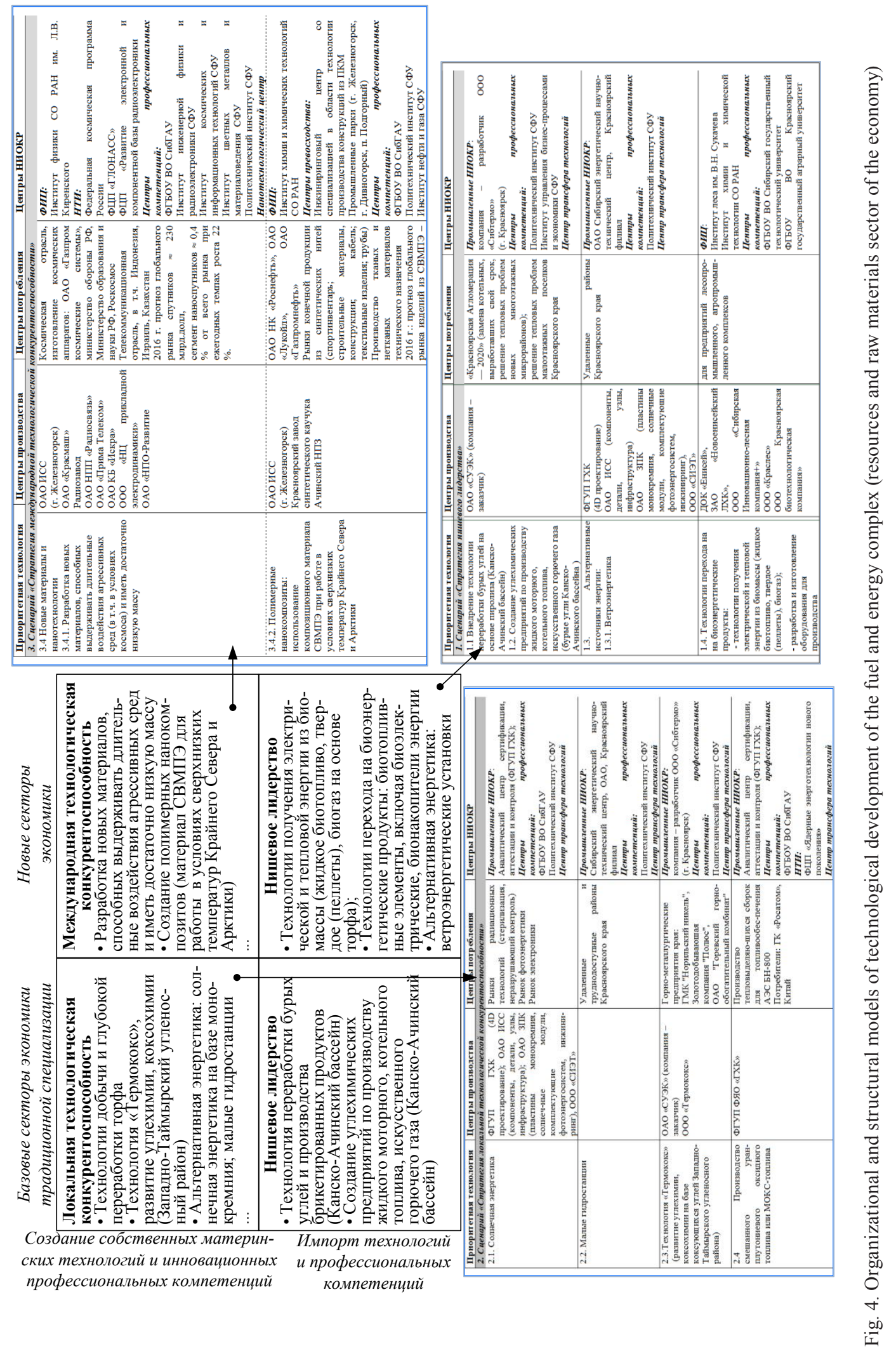


conditions and growth rates to 2030 and to highlight socio-economic, technological and multiplicative effects.

\section{References}

Corden, W., Neary, J. (1982). Booming sector and deindustrialization in a small open economy. In The Economic Journal, (92), 825-848. Available at: http://www.jstor.org/ stable/2232670?seq=1\#page_scan_tab_contents

Corden, W. (1984). Booming sector and Dutch disease economics: survey and consolidation. In Oxford Economic Papers, (36), 359-380. Available at: http://www.bresserpereira.org.br/terceiros/ cursos/2013/07.09.corden.pdf

Ermakova, Zh.A.Tekhnologicheskie prioritety kak osnova nauchno-tekhnicheskogo razvitiia promyshlennogo kompleksa regiona [Technological priorities as the basis for the scientific and technical development of the region's industrial complex]. In Vestnik OGU [OSU bulletin], 8 (144), 105-109.

Innovatsionnyi Krai - 2020. Strategiia razvitiia Krasnoiarskogo kraia na period do 2020 goda [Innovative Territory - 2020. The strategy of development of the Krasnoyarsk Krai up to 2020] (2011). Pravite'stvo Krasnoiarskogo kraia [Krasnoyarsk Krai Government].

Mikheeva, N.N. (2009) Dvukhsektornaia model' razvitiia resursodobyvaiushchikh regionov [Two-sector model of resource-producing regions]. In Region: ekonomika i sotsiologiia [Region: economics and sociology], 2, 23-42

Nazarova, N.E. (2007). Mnogoukladnost' ekonomiki i tekhniko-innovatsionnyi potentsial ekonomicheskogo razvitiia Rossii [Multistructurality of the economy and technology and innovation potential of the economic development of Russia].

Problemy sovremennoi ekonomiki [Challenges of Modern Economy], 3(23), available at: http:// www.m-economy.ru/art.php?nArtId=1472

Regiony nuzhdautsia $v$ "umnoi spetsializatsii" [The regions need "smart specialisation"]. Available at: https://iq.hse.ru/news/177668721.html

Samusenko, S., Bukharova, E. (2015). Industrial Policy: Barriers and Limitations for Innovation Activity Growth of Enterprises in the Conditions of Multi-dimensional Economy of Siberia. In Journal of Siberian Federal University. Humanities \& Social Sciences, 8, 83-97

Sergeev, V.M., Alekseenkova, E.S.Stanovlenie gosudarstva i modeli innovatsionnogo razvitiia [Emerging of the state and the model of innovative development]. Available at: www.mgimo.ru/ files/34545/doklad_politolog_1.doc

Sipols, O.V. (2010). Novyi anglo-russkii slovar' spravochnik. Ekonomika [New English-Russian Reference Dictionary. Economics]. Moscow, Flinta, Nauka.

"Smart specialisation" (2015). Strategies of sustainable development. European Economic Commission. Committee on economic cooperation and integration. Geneva, September 3-4.

"Strategies of innovative development of the Russian Federation for the period up to 2020" (approved by the Decree No. 2227-r of the Russian Federation Government on December 08, 2011). 


\title{
Модель управления развитием регионов \\ на основе SMART-технологий: \\ «умная специализация»
}

\author{
И.В. Филимоненко, 3.А.Васильева \\ ${ }^{a}$ Сибирский федеральный университет \\ Россия, 660041, Красноярск, пр. Свободный, 79
}

Целью исследования является обоснование необходимости смены концептуальных подходов к управлению развитием экономики сырьевых регионов в условиях влияния глобальных вызовов и изменения моделей пространственного развития. Новые тенденции мирового развития снижают эффективность использования традиционных методов и механизмов управления сырьевым регионом, которые базируются на сохранении роли лидирующего ресурсно-сырьевого сектора, доминирующем влиянии крупных индустриально-сырьевых холдингов, ограниченных полномочиях региональной власти в управлении ресурсно-сырьевым потенциалом региона.

В статье на основе соотношения технологических и рыночных параметров исследуются возможности применения моделей мультисекторного развития для противостояния глобальным вызовам за счет формирования новых стремительно развиваюшихся секторов в экономике сырьевых регионов. С учетом специфики развития сырьевых регионов раскрыта роль быстроразвивающихся секторов в технологическом и инновационном развитии региона. В иелях формирования в экономике регионов новых быстроразвиваюшихся секторов обоснована целесообразность применения подхода к управлению развитием региона на основе концепциии «умная специализаџия» за счет внедрения SMART-технологий в процессы производства и управления как в традиционных отраслях специиализации, так и в новых сферах деятельности.

Использование концеепции «умная спецчиализацчия» для управления сырьевым регионом позволило определить сиенарии развития экономики, дифференцированные по маситабам технологического лидерства, - «нишевое лидерство», «локальная технологическая конкурентоспособность», «международная технологическая конкурентоспособность». Применение метода стратегического позиционирования в координатах матричного пространства «сектор экономики - источник новых знаний и технологий/профессиональные компетенции» дало возможность сформировать стратегии и сценарии технологического развития сырьевого региона. В качестве параметров стратегического позиционирования использованы «технологии (собственные материнские; заимствованные)»; «профессиональные компетенции (базовые сущуествующей специиализации; инновационные)»; "базовые секторы региональной специализации»; «новые стремительно развивающиеся».

Апробация модели управления развитием сырьевых регионов на основе концепции «умная специилизация» на примере Красноярского края позволила подтвердить гипотезу о наличии в структуре экономики «стремительно развивающихся секторов» (высокотехнологичный, «экономика знаний»), определить необходимье условия развития и темпь роста до 2030 г., выделить сочиильно-экономические, технологические и мультипликативные эффекты.

Ключевые слова: управление развитием региона, глобальные вызовы, мультисекторная модель, стремительно развиваюшийся сектор, концепџия «умная специиализация», сиенарии технологического развития.

Научная специальность: 08.00.00 - экономические науки. 